\title{
Evaluation of Nutritional Status of Rural Bengalee Primary School Boys (6-9 Years) in Comparison to Indian Children
}

\author{
Subrata Dutta and Prakash Chandra Dhara
}

\author{
Vidyasagar University, Ergonomics and Sports Physiology Division, Dept. of Human Physiology with \\ Community Health, Paschim Medinipur-721 102, West Bengal, India
}

\begin{abstract}
A cross sectional study was undertaken to determine nutritional status and growth pattern of 410 rural primary school boys (6-9 years of age) belong from lower socioeconomic status according Kuppuswamy's socioeconomic scale (2012) in West Midnapore District of West Bengal. The daily nutritional intake of the children was measured by weighing raw and cooked foods and also by $24 \mathrm{hrs}$ recall method. The body mass indexes (BMI), body composition, protein/calory adequacy status, protein-energy ratio of the primary school boys were measured to assess the nutritional status. The food and nutrient intake of the subjects were compared with their respective Indian values (NNMB, 2002). The diet of rural school boys was found to be imbalanced with plenty intake of milk and lower in intake of cereals, pulses but higher in intake of vegetables than that of their Indian counterpart. It was observed that the diets are predominantly more deficient in calories than protein. Most of the boys had normal body weight and only a little number of boys was overweight or underweight and the protein energy ratio is lower than ICMR recommended value except the age group of 7 years and the maximum percentage (about 20\%) of underweight boys is found in the age group of 9 years. It was further observed that there was a significant correlation between body composition and $\mathrm{BMI}(\mathrm{p}<0.001)$.
\end{abstract}

Keywords: Primary school boys, Kuppuswamy's socioeconomic scale, BMI, Body composition, Protein/calory adequacy status, Protein-energy ratio, Nutritional status.

\section{INTRODUCTION}

Growth is at its peak during the school age, there are a number of changes take place with which they have to cope with. The nature of the children's growth depends upon nutritional status and environmental condition, which interacts with other socio-economic, bio-physiological, and physical environmental factors [1]. When a child's intake of food falls below a standard reference, growth slows. Diet should be eaten in sufficient quantity daily to provide the needed energy [2]. A "balanced diet" is one, which contains different types of foods in such quantities and proportions that the need for calories, minerals, vitamins and other nutrients are adequately met and a small provision is made for extra nutrients to withstand short durations of leanness (Gopalan et al. 1971). The nutrition status influences the growth of the children [3]. The physical growths of the student depend upon changes of body dimensions as a function of age (Martin 1954). The type and quantity of various foods is based on socioculture and economic considerations [2]. Children from better socioeconomic classes would naturally have better nutrition and better environment [4]. A large number of diet and nutrition surveys have been carried out by different workers on the nutritional status of school children. The results have shown that a majority

*Address correspondence to this author at the Vidyasagar University, Ergonomics and Sports Physiology Division, Dept. of Human Physiology with Community Health, Paschim Medinipur-721 102, West Bengal, India; Tel: +919433226695; E-mail: prakashdhara@rediffmail.com of the school children consume inadequate diets and are malnourished. During the year 2000-2001 the NNMB carried out diet and nutrition assessment of the rural population of different states in India [5]. In general, the median intakes of all the nutrients were less than the RDA in all the States. In planning a diet for the community, foods have to chosen in proper amounts and also keeping in view the dietary habits and availability of foods. One of the aims of nutrition research has been to determine physiological requirements of various nutrients by different age and sex groups. In view of all above mentioned aspects, the present investigation was studied on Bengalee rural children. The main objective was to assess the pattern of food intakes as well as the nutritional status of the children to provide baseline information on the growth and development of the school students in the rural areas of west Bengal.

\section{MATERIAL AND METHODS}

\section{Study Population and Sampling}

The present study was carried out in the 20 rural primary schools, located at remote areas of Sadar East Circle in Paschim Medinipur District. For the study, 410 primary school students having age range 6 to 9 years were selected at random on the basis of lower socioeconomic class according to the Kuppuswamy's socioeconomic scale (2012) [6]. The total numbers of subject were classified into four major groups on the basis of their age viz. 6 years $(n=101), 7$ years $(n=102)$, 8 years $(n=103)$, and 9 years $(n=104)$. 


\section{Evaluation of Nutritional Status}

Nutritional status was measured by three ways:

\section{Dietary Assessment}

The nutritional status of primary school students was evaluated by weighing raw foods and cooked food materials [3]. At first 479 children (age 6-9 years) were randomly selected for dietary assessment. The respective House Holds were visited by the investigator and their economic statuses were assessed according to Kuppuswamy's socioeconomic scale: update of income range of the year 2012 [6]. Among them 410 households were belonged to lower economic status having monthly income Rs 1520-7593 according to the Kuppuswamy's socioeconomic scale and students $(n=410)$ of those households were taken for further studies of dietary assessment. According the 24 hours recall and one day food record was investigated and assessed five times in each house hold. The first visit included a 24-hour recall and questions concerning economic status consist of education, occupation and family income per month. In the next visit the second 24-hour recall was completed, instructions for the 1-day weighed food record, the weight of the food stuff taken personally or check the weight of raw foods just before cooking and the weight of the cooked food to be consumed. The process was repeated for three consecutive days and the average was taken for calculation which was to be completed by the child assisted by the parents. Volumes and portion sizes for the 24-hour recalls were estimated using measuring cups and spoons. For the 1-day-food record individual digital kitchen scales were used. In this method from the quantity of the food the amounts of energy, carbohydrate, protein, and fat consumed by the children were calculated by using food composition table [7]. The daily intakes of various nutrients were computed and compared with 'Recommended Dietary Allowances for Indians' (RDI) suggested by the NNMB [5].

\section{By Anthropometric Measurements}

Different body dimensions of the subjects were taken by means of anthropometer (Holtain), sliding caliper and steel tape by adopting proper landmark definition and standard measuring techniques [8, 9]. The all data were taken with the mean of three consecutive trials. The following anthropometric measurements were taken:

\section{Weight}

The body weight of the subjects was measured by portable weighing machine. All subjects were asked to wear shorts and banian and were bare footed during measurements.

\section{Height}

The vertical distance from the standing surface to the top was measured by anthropometric rod.

\section{BMI}

In this study different growth patterns of the children of different age groups were evaluated though their cross sectional data. Body weight $(\mathrm{Kg})$ of a subject dividing by the squared value of his height (meter), body mass index was calculated.

Body mass index (B.M.I.) = Weight $(\mathrm{Kg}) /$ Height ${\text { (meter })^{2}}^{2}$

\section{Body Composition}

The body composition of the subject was determined by measuring the skin-fold thickness. The chest, abdomen and thigh skin folds were measured in male subjects. The skin fold caliper (Holtain) was used for these measurements. The measurements were taken under standardized condition and using proper landmarks [10].

The anatomic sites that were used for skin fold measurements are as follows:

1. Chest: Midway between the anterior fold of the axilla and the nipple.

2. Abdomen: A vertical fold about $1 \mathrm{~cm}$ to the right of the umbilicus.

3. Thigh: A vertical fold on the front of the right thigh halfway between the hip and the knee.

From the skin fold data total weight of body fat and lean body weight were determined by the calculating the body density and percentage of body fat of boys [11-13]. The following formulae were used:

(a) Body density $(\mathrm{gm} / \mathrm{cc})=1.10938-0.0008276$ (sum of chest, abdomen and thigh skin folds) + 0.0000016 (sum of the same three skin folds) ${ }^{2}$ 0.0002574 (age in years). 
(b) Percentage of fat $=\{(4.95 \div$ Body density $)-4.50$
\}$\times 100$

(c) Total weight of fat $=($ Weight in $\mathrm{kg} \times$ Percentage of fat) $\div 100$

(d) Lean body weight $=$ Total weight $(\mathrm{kg})-$ Total weight of fat $(\mathrm{kg})$.

\section{Evaluation of Growth Patterns}

The physical growths of the children were evaluated by noting changes of their body dimensions as a function of age. The growth velocities of the children were determined by noting changes of his stature $(\mathrm{cm})$ and weight $(\mathrm{kg})$ per year. Study of height and weight were done in three consecutive years i.e., March-2009, March-2010 and March-2011. The growth rate of the studied children was calculated by Tanner Stage Calculator for Boys, Version-2.3 [14]. The following characteristics were taken for measurement of Tanner Stages, viz., grown in the last year, voice, body hair, chest and face.

\section{Protein /Calorie Adequacy Status}

The individuals of different groups were categorized according to their protein/calorie adequacy status. The Expert Committee of Indian Council of Medical Research (ICMR) has suggested requirements for energy as the recommended allowances. The individuals consuming less than recommended requirements were considered as consuming 'inadequate' amounts of protein or energy.

\section{Protein-Energy Ratio}

It is one way of evaluating foods as source of protein and is used to determine what percent of their energy value is supplied by their protein content. The following ratio was used:

Protein-Energy ratio $=($ Energy from protein $/$ Total energy in diet) $\times 100$

\section{Analysis of Data}

To identify the causative factors on the nutritional status of the Bengalee primary school children, data analysis had been made with the help of a software package on 'STATISTICA' (Version 8.0). The mean and standard deviation was calculated for all data. 't'test and correlation Multiple means were compared with the one-way ANOVA using post-hoc comparison only when the results of the ANOVA were significant at a level of $p<0.05$.

\section{RESULTS}

In Figure 1, the percentages of socio-economic status of 479 House Holds according to the modified Kuppuswamy Scale, 2012 is presented. Among the 479 studied House Holds, 410 House Holds were selected who belonged from lower socioeconomic status (lower, upper lower and lower middle) according to the modified Kuppuswamy economic scale [6] and had par capita monthly income of Rs 1520-7593. The average per capita monthly income was Rs.4657. The major studied House Holds (39.5\%) were in lower middle economic class. The lower socioeconomic status of the families might be related to the paucity of income sources, low wage rate, poor communication system, fewer numbers of schools etc.

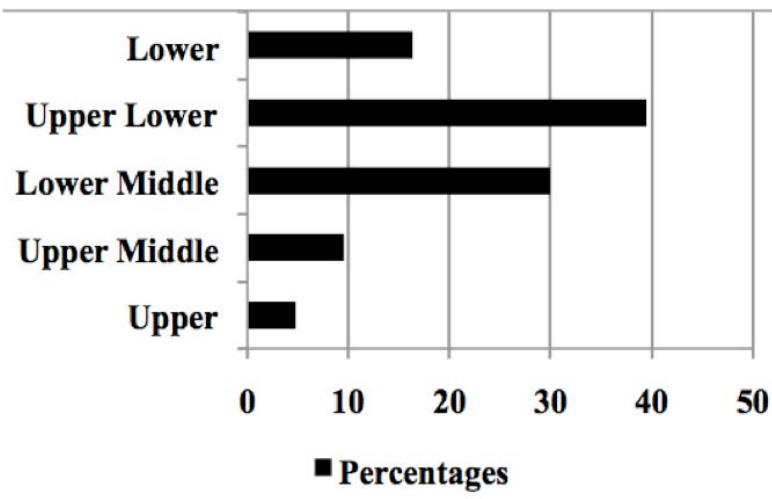

Figure 1: Percentages of socio-economic status of House Holds according to the modified Kuppuswamy Scale, 2012.

The rural primary school boys used to take food items of different groups of foods. The mean, SD and range of different food items consumed by the subjects have been presented in Table 1.

From the results it is noted that the daily food intake increases with increase of age. This may be related with the increased growth and body development. Among the children of all age groups, the boys of 6 years consumed lower amount of cereals, pulses, vegetables, meat and fish and other food items, except the milk, than the children of other age groups. The diets consumed in India are highly cereal- based. In the case of a majority of population, cereals form almost the bulk of the diet [15]. It is also observed that cereals are forming the main bulk of the diet in the boys of the present investigation.

In the Table 2, daily food intake of the children is compared with that of NNMB (2002) recommended 
Table 1: Mean \pm SD and (Ranges) of Daily Dietary Intake of School Children in Different Age Groups

\begin{tabular}{|c|c|c|c|c|}
\hline \multirow{2}{*}{$\begin{array}{l}\text { Foods } \\
\text { (gm) }\end{array}$} & \multicolumn{4}{|c|}{ Age groups } \\
\hline & 6years & 7 years & 8 years & 9 years \\
\hline Cereals & $\begin{array}{c}237.41 \pm 37.96 \\
(140-315)\end{array}$ & $\begin{array}{c}251.35 \pm 43.65 \\
(175-355)\end{array}$ & $\begin{array}{c}277.53 \pm 49.50 \\
(200-370)\end{array}$ & $\begin{array}{c}300.16 \pm 50.12 \\
(210-390)\end{array}$ \\
\hline Pulses & $\begin{array}{c}22.79 \pm 4.40 \\
(14-32)\end{array}$ & $\begin{array}{c}25.11 \pm 4.60 \\
(16.0-35.0)\end{array}$ & $\begin{array}{c}30.08 \pm 4.68 \\
(20.0-40)\end{array}$ & $\begin{array}{c}40.38 \pm 8.07 \\
(25-55)\end{array}$ \\
\hline Green leafy vegetables & $\begin{array}{c}36.40 \pm 7.29 \\
(25.0-52.0)\end{array}$ & $\begin{array}{c}48.95 \pm 10.59 \\
(30-55)\end{array}$ & $\begin{array}{c}55.54 \pm 10.55 \\
(30-75)\end{array}$ & $\begin{array}{c}62.99 \pm 5.86 \\
(50-75)\end{array}$ \\
\hline Other vegetables & $\begin{array}{c}28.66 \pm 7.24 \\
(20-45)\end{array}$ & $\begin{array}{c}30.65 \pm 7.43 \\
(20-55)\end{array}$ & $\begin{array}{c}39.61 \pm 11.38 \\
(25-60)\end{array}$ & $\begin{array}{c}37.75 \pm 10.50 \\
(25-60)\end{array}$ \\
\hline Roots and tubers & $\begin{array}{c}23.69 \pm 9.83 \\
(20-55)\end{array}$ & $\begin{array}{c}29.95 \pm 11.86 \\
(20-55)\end{array}$ & $\begin{array}{c}30.09 \pm 10.17 \\
(25-70)\end{array}$ & $\begin{array}{c}44.46 \pm 12.87 \\
(25-70)\end{array}$ \\
\hline Fruits & $\begin{array}{c}22.79 \pm 5.83 \\
(10-35)\end{array}$ & $\begin{array}{c}24.33 \pm 7.27 \\
(15-50)\end{array}$ & $\begin{array}{c}25.86 \pm 9.63 \\
(15-55)\end{array}$ & $\begin{array}{c}27.07 \pm 8.08 \\
(20-55)\end{array}$ \\
\hline Milk & $\begin{array}{c}85.21 \pm 27.61 \\
(50-130)\end{array}$ & $\begin{array}{c}69.21 \pm 26.76 \\
(25-125)\end{array}$ & $\begin{array}{c}72.54 \pm 29.38 \\
(40-150)\end{array}$ & $\begin{array}{c}70.42 \pm 33.34 \\
(50-150)\end{array}$ \\
\hline Oils & $\begin{array}{c}11.12 \pm 2.88 \\
(6-20)\end{array}$ & $\begin{array}{c}11.26 \pm 2.74 \\
(8-20)\end{array}$ & $\begin{array}{c}12.15 \pm 3.14 \\
(7-20)\end{array}$ & $\begin{array}{c}11.86 \pm 2.4 \\
(7-20)\end{array}$ \\
\hline Meat and Fish & $\begin{array}{c}21.36 \pm 5.41 \\
(12-36)\end{array}$ & $\begin{array}{c}21.56 \pm 6.17 \\
\quad(12-34)\end{array}$ & $\begin{array}{c}25.55 \pm 5.00 \\
(15-40)\end{array}$ & $\begin{array}{c}24.89 \pm 5.06 \\
(15-40)\end{array}$ \\
\hline Eggs & $\begin{array}{c}27.31 \pm 8.50 \\
(15-50)\end{array}$ & $\begin{array}{c}33.86 \pm 12.43 \\
(15-60)\end{array}$ & $\begin{array}{c}40.93 \pm 15.18 \\
(15-70)\end{array}$ & $\begin{array}{c}56.34 \pm 16.16 \\
(25-90)\end{array}$ \\
\hline Sugars & $\begin{array}{c}42.24 \pm 9.56 \\
(25-70)\end{array}$ & $\begin{array}{c}48.15 \pm 12.58 \\
(25-85)\end{array}$ & $\begin{array}{c}57.01 \pm 13.95 \\
(25-90)\end{array}$ & $\begin{array}{c}51.93 \pm 13.37 \\
(25-90)\end{array}$ \\
\hline
\end{tabular}

Table 2: Comparison of Mean Values (Between Observed Data and NNMB-2002. Recommended Data) of Foodstuffs Taken by the Boys of 6-7 Years and 8-9 Years

\begin{tabular}{|c|c|c|c|c|c|}
\hline Food items & $\begin{array}{c}\text { Balanced diets for age } \\
\text { groups 6-9 years } \\
\text { (recommended by NNMB } \\
(\mathrm{gm})\end{array}$ & $\begin{array}{c}\text { Foodstuffs taken by } \\
\text { the boys of 6-7 years } \\
\text { (present } \\
\text { investigation) (gm) }\end{array}$ & $\begin{array}{l}\% \text { of food intake } \\
\text { according to RDA }\end{array}$ & $\begin{array}{c}\text { Foodstuffs taken by } \\
\text { the boys of } 8-9 \text { years } \\
\text { (present investigation) } \\
\text { (gm) }\end{array}$ & $\begin{array}{l}\% \text { of food } \\
\text { intake } \\
\text { according to } \\
\text { RDA }\end{array}$ \\
\hline Cereals & 270 & 255.7 & 94.7 & 297.3 & 110.1 \\
\hline Pulses & 35 & 24.6 & 70.3 & 34.5 & 98.6 \\
\hline $\begin{array}{c}\text { Leafy } \\
\text { vegetables }\end{array}$ & 50 & 42.8 & 85.6 & 58.6 & 117.2 \\
\hline $\begin{array}{c}\text { Other } \\
\text { vegetables }\end{array}$ & 30 & 28.8 & 96.0 & 34.1 & 113.6 \\
\hline $\begin{array}{l}\text { Roots and } \\
\text { tubers }\end{array}$ & 20 & 26.8 & 134.0 & 36.7 & 183.5 \\
\hline Milk & 250 & 82.7 & 33.1 & 70.6 & 28.2 \\
\hline Oil & 25 & 11.3 & 45.2 & 12.0 & 48.0 \\
\hline Sugar & 40 & 46.3 & 115.8 & 53.7 & 134.2 \\
\hline
\end{tabular}

values for primary school boys of $6-9$ yrs of age. It is observed from the Table 2 that the values of cereals, pulses, leafy vegetables, other vegetables, milk and oil taken by the age group 7-8 years were lesser (5.3\%, $29.7 \%, 14.4 \%, 4 \%, 66.9 \%$ and $54.8 \%$ respectively) but took $34 \%$ and $15.8 \%$ higher amount of roots and tuber, 
Table 3: Frequency of Consumption of Various Foods by the Children $(n=410)$

\begin{tabular}{|c|c|c|c|}
\hline \multirow{2}{*}{ Foods } & \multicolumn{3}{|c|}{ Frequency of consumption (\%) } \\
\cline { 2 - 4 } & Daily & Frequently & Rarely \\
\hline \hline Cereals Products & 100 & - & 23 \\
\hline Pulses ( Dhals) & 66 & 11 & 16 \\
\hline Green Vegetables & 27 & 57 & 34 \\
\hline Other Vegetables & 42 & 24 & 69 \\
\hline Fruits & 4 & 27 & - \\
\hline Oil & 100 & - & 62 \\
\hline Meat and Fish & 11 & 27 & 39 \\
\hline Eggs & 20 & 41 & 47 \\
\hline Milk & 13 & 22 & 33 \\
\hline
\end{tabular}

and sugar than that of the recommended values of NNMB, 2002. On the other hand, the intake of cereals, pulses and vegetables by the boys of 8 to 9 years are more or less the same with the recommended values of NNMB. But the intake of milk and oil, in this group, is notably lower than the recommended amounts. The daily meal pattern in most of the families consisted cereals as major food item. It was revealed from the results that all food staffs except milk taken by the boys of the age group 6-9 years were lower than that of the age group of 8-9 years.

Food Frequency Questionnaires (FFQs) are commonly used in epidemiologic studies to assess long-term nutritional exposure. In the Table 3 , the frequency of consumption of various types of foods has been divided into three categories, viz., daily (1 $1-2$ times or more per day), frequently (1-2times or more per week), and rarely (1-2times or more per month) [16]. The results revealed that rural boys consume cereals every day. Higher percentages $(66 \%)$ of rural boys consumed pulses (dhal) daily. Among vegetables, green vegetables were mostly consumed frequently but daily consumption of other vegetables (42\%) was higher but daily fruit consumption (4\%) was much lower. A low percentages of children consumed milk, meat and fish. However, eggs $(20 \%)$ were consumed more often than meat and fish (11\%).

The nutrient consumption of the present children was lesser than that of the RDA. The intake of protein in the age groups of $6 \mathrm{yrs}$ was $23.5 \mathrm{gm}$ in comparison to the RDA value ( $30 \mathrm{gm}$ ). For age groups $7 \mathrm{yrs}, 8 \mathrm{yrs}$ and $9 \mathrm{yrs}$, they were $66.7 \%, 82.1 \%$ and $81.6 \%$ of RDA respectively.

Energy is a prime requisite for body function and growth. The intake of energy was increased due to increment of age. The energy consumption of boys of the age group 6 yrs and 7 yrs was $79.8 \%$ and $74.2 \%$ of RDA respectively. The intake of energy of the boys of 8 years and 9 years age groups were $22.61 \%$ and $8.41 \%$ lower than RDA values recommended by NNMB-2002 (Table 4).

Table 4: Comparison of Nutrient Intake Between Present Study and NNMB-2002 Recommended Data

\begin{tabular}{|c|c|c|c|c|c|c|}
\hline \multirow[t]{2}{*}{ Age groups } & \multicolumn{6}{|c|}{ Nutrients intake } \\
\hline & $\begin{array}{c}\text { Carbohydrates } \\
\text { (gm) }\end{array}$ & $\begin{array}{l}\text { Proteins } \\
\text { (gm) }\end{array}$ & $\begin{array}{c}\text { RDA (gm) } \\
\text { (NNMB-2002) }\end{array}$ & Fats (gm) & Energy (Kcal) & $\begin{array}{c}\text { RDA (gm) } \\
\text { (NNMB-2002) }\end{array}$ \\
\hline 7 yrs $(n=102)$ & $271.55 \pm 37.25$ & $27.35^{\#} \pm 2.42$ & 41 & $23.74 \pm 3.37$ & $1447.73 \pm 161.25$ & 1950 \\
\hline 8 yrs $(n=103)$ & $312.41 \pm 42.79$ & $33.67 \pm 3.63$ & 41 & $37.02 \pm 5.01$ & $1509.09^{\wedge} \pm 164.30$ & 1950 \\
\hline F Values & $34.28(p<0.01)$ & $28.45(p<0.01)$ & & $18.98(p<0.01)$ & $3.32(p<0.05)$ & \\
\hline
\end{tabular}

${ }^{*} p<0.01,{ }^{\wedge} p<0.001,{ }^{\#} p<0.02 ; n$ indicates numbers of children were taken for the study. 
Table 5: Protein-Calorie Adequacy Status (\%) of 6-9 Year Children

\begin{tabular}{|c|c|c|c|c|c|c|}
\hline Age Groups & P- C- (\%) & ${ }^{*}$ P- C- (\%) & P+C- (\%) & ${ }^{*} \mathrm{P}+\mathrm{C}-(\%)$ & $\mathrm{P}+\mathrm{C}+(\%)$ & ${ }^{*} \mathrm{P}+\mathrm{C}+(\%)$ \\
\hline 6 yrs $(n=101)$ & $57.4 \%$ & $8.9 \%$ & $22.7 \%$ & $62.5 \%$ & $7.9 \%$ & $28.6 \%$ \\
\hline 7 yrs $(n=102)$ & $52 \%$ & \multirow{3}{*}{$7.2 \%$} & $18.6 \%$ & \multirow{3}{*}{$62.2 \%$} & $10.8 \%$ & \multirow{3}{*}{$30.6 \%$} \\
\hline 8 yrs $(n=103)$ & $44.6 \%$ & & $30.1 \%$ & & $13.6 \%$ & \\
\hline 9 yrs $(n=104)$ & $58.6 \%$ & & $24 \%$ & & $8.65 \%$ & \\
\hline Total $(n=410)$ & $53.17 \%$ & & $29.9 \%$ & & $10.2 \%$ & \\
\hline
\end{tabular}

$\mathrm{n}$ indicates numbers of children were taken for the study. P-: Protein Inadequate, $\mathrm{P}_{+}$: Protein Adequate, $\mathrm{C}_{+}$: Calorie Adequate, $\mathrm{C}_{-}$: Calorie Inadequate; ${ }^{*} \mathrm{NNMB}$ study-2002.

It was noted that only $10.2 \%$ of the children $(6-9$ years) consumed adequate amounts of both protein and energy, while about $53.17 \%$ of them consumed diets, which was deficient in both the items (Table 5). It was observed that about $8 \%$ children of 6 years consumed adequate amount of both proteins and calories which was $20.7 \%$ lower from NNMB-2002 recommended values. It was also revealed that the children of 9 years were most deficient of both protein and calories (58.6\%) among the children of all age groups. About $29.9 \%$ of the children had adequate amounts of protein but inadequate amounts of calories. Thus, it was observed that the diets were predominantly more deficient in calories than protein, with about $84 \%$ of the children consuming inadequate amounts of calories.

In the present study the protein energy ratio of the children was $10.14 \%, 4.88 \%$, and $6.41 \%$ lower in for the age groups of 6 yrs, 8 yrs and 9 yrs respectively than the ICMR recommended values of the corresponding age groups. The protein energy ratio was slightly higher than ICMR recommended value in case of age group 7 years. As in $14.5 \%$ of boys, the protein energy ratio was lesser than $4 \%$; the subjects were referred as unable to eat enough to satisfy protein requirements (Table 6).

The growth pattern of the children was expressed in terms of gain in weight $(\mathrm{Kg} /$ year) and height ( $\mathrm{cm} /$ year), which have been shown in the Table 7 . The rate of increment was increased gradually with the advancement of age and it reaches to its maximum at the age of 9 years within the studied age groups (Figure 2).

Growth velocities in respect to weight gain per year of the children of the present investigation and that of I.C.M.R (2010) [17] data are shown in Figure 3. The peak velocity of height and weight are found at the age

Table 6: Comparison of Protein-Energy Ratio Between Observed Data and Recommended Values

\begin{tabular}{|c|c|c|c|}
\hline Age groups & $\begin{array}{c}\text { ICMR Recommended Protein Energy } \\
\text { ratio (\%) }\end{array}$ & $\begin{array}{c}\text { Protein Energy ratio (\%) in } \\
\text { study }\end{array}$ & $\begin{array}{c}\text { Frequency Protein Energy ratio } \\
\text { (\%)less than 4\% }\end{array}$ \\
\hline \hline 6 yrs $(n=101)$ & 6.9 & 6.2 & 14 \\
\hline 7 yrs $(n=102)$ & 6.9 & 7.0 & 2 \\
\hline 8 yrs $(n=103)$ & 8.2 & 7.8 & 9 \\
\hline 9 yrs $(n=104)$ & 8.2 & 7.3 & 4 \\
\hline
\end{tabular}

$\mathrm{n}$ indicates numbers of children were taken for the study.

Table 7: Increment of Weight $(\mathrm{Kg})$ and Height (c.m.) Per Year for the Children of 6 to 9 Years

\begin{tabular}{|c|c|c|c|}
\hline Age groups & Weight gain $(\mathrm{Kg} /$ Year) & ICMR-2010 recommended weight gain (Kg/Year) & Height (cm/ Year) \\
\hline \hline 6 yrs $(n=101)$ & 1.6 & 2.3 & 1.98 \\
\hline 7 yrs $(n=102)$ & 2.2 & 2.5 & 2.86 \\
\hline 8 yrs $(n=103)$ & 2.1 & 2.8 & 3.22 \\
\hline 9 yrs $(n=104)$ & 2.5 & 2.8 & 4.35 \\
\hline
\end{tabular}

$\mathrm{n}$ indicates numbers of children were taken for the study. 


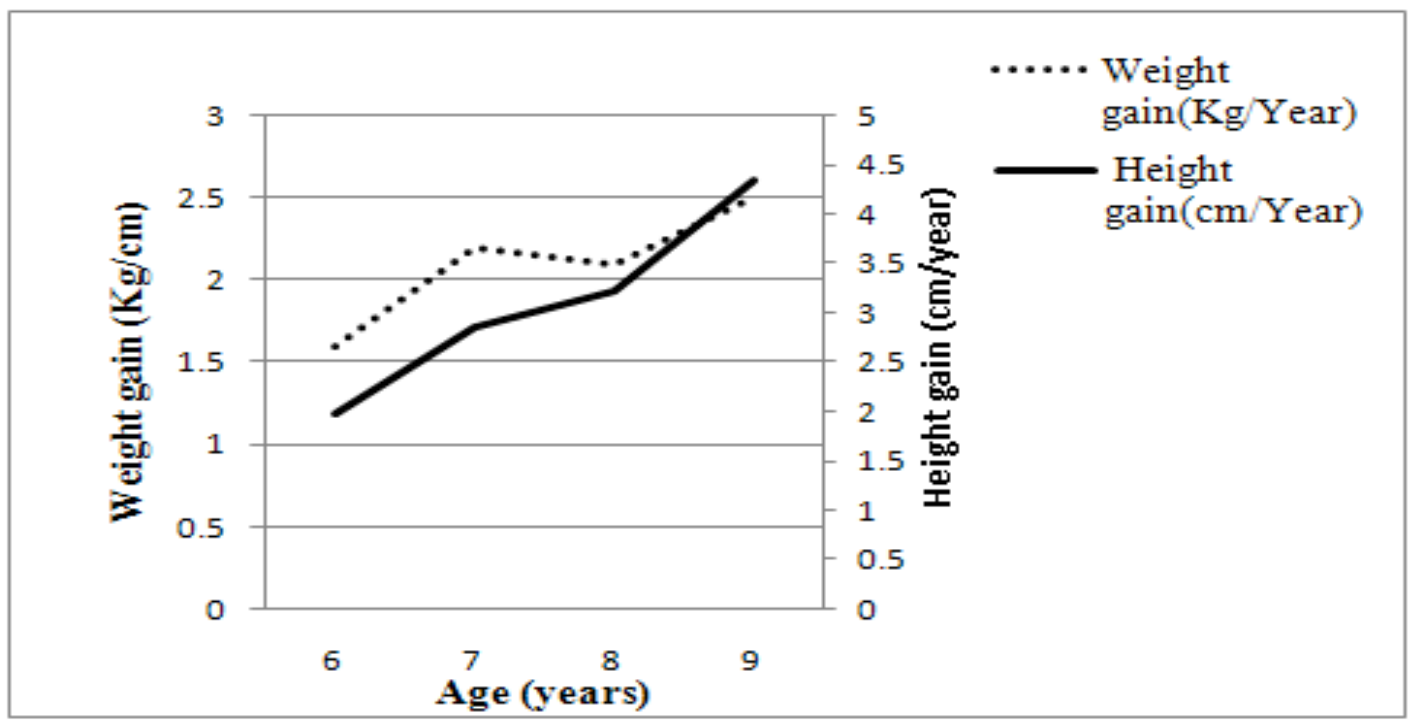

Figure 2: Comparison between weight $(\mathrm{Kg})$ and height $(\mathrm{cm})$ as function of age.

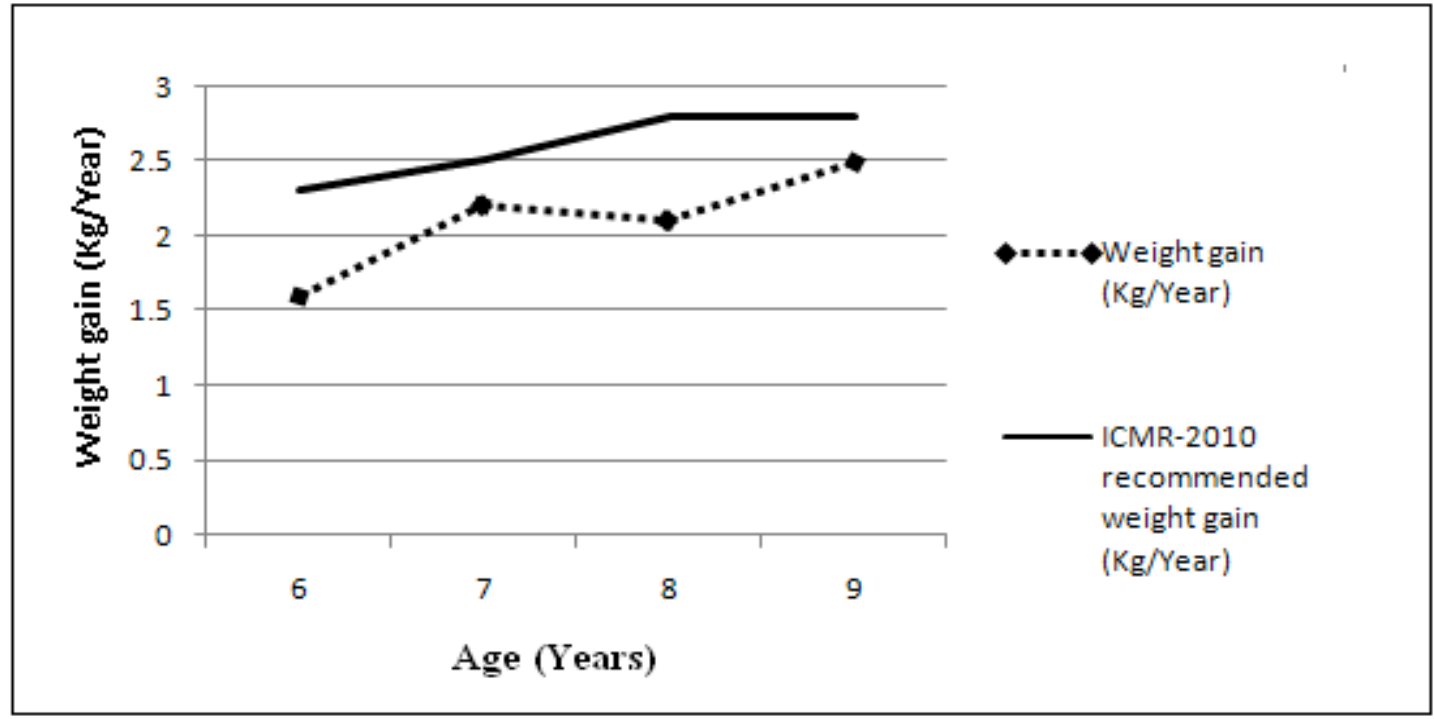

Figure 3: Velocity curve of weight $(\mathrm{Kg})$.

of 9 years. From the above study, it was found that the weight gain/year of rural Bengalee primary school boys were lower than the recommended weight gain (ICMR 2010) of average Indian children of same age group.

From the Table 8, it was revealed that according to the Tanner Stage assessment, the studied population were belong to Stage-I. Their typical growth rate ranged from 2-6 cm per year. Most of the children were belonged from Tanner Stage-I as they possesses the characteristics of Stage-I i.e., voice was the same as it had been since childhood, no body hair or very fine hair which was not easily noticed, areola was barely noticeable and followed the skin contour of the chest etc. about $8 \%$ of the age groups of 9 years had showed the Stage-II viz., voice box became noticeable, very fine hairs on legs and arms, a darker ring around nipples etc.

From the Table 9, different anthropometric dimensions of Bengalee primary school boys were compared with the Indian, Malaysian and African rural primary school boys (belonging from low income group and also all income groups). From the table, it had been observed that standing height and weight was higher in Bengalee rural boys than that of the Indian average rural boys. Bengalee rural children had 5.1\%$11.3 \%$ higher values in height than the NNMB values of Indian rural children of same age groups. But the BMI was lower (3.5-5.8\%) in Bengalee school boys than that of the Indian boys of same age group (6-9 years). 
Table 8: Assessment of Tanners Stage among the Bengalee Primary School Children

\begin{tabular}{|c|c|c|c|}
\hline \multirow{2}{*}{} & \multicolumn{2}{|c|}{$\begin{array}{c}\text { Growth Rate according Tanner Stage Calculator } \\
\text { (Version 2.3) }\end{array}$} \\
\cline { 2 - 4 } & Estimated Tanner Stage & \multicolumn{2}{c|}{ Development Stage } \\
\cline { 2 - 4 } & & Stage-I (\%) & $0 \%$ \\
\hline \hline 6 Years $(n=101)$ & 1.8 & $100 \%$ & $3 \%$ \\
\hline 7 Years $(n=102)$ & 2.3 & $97 \%$ & $3 \%$ \\
\hline 8 Years $(n=103)$ & 3.1 & $97 \%$ & $8 \%$ \\
\hline 9 Years $(n=104)$ & 4.0 & $92 \%$ & 3 \\
\hline
\end{tabular}

$\mathrm{n}$ indicates numbers of children were taken for the study.

Table 9: Comparison of Weight (Kg) and Height (c.m.) among the Bengalee Children (in Present Study) with Indian Children, Malaysian Children and African Children of Studied Age Groups

\begin{tabular}{|c|c|c|c|c|c|c|c|c|c|c|c|c|}
\hline \multirow{2}{*}{$\begin{array}{c}\text { Age } \\
\text { (years) }\end{array}$} & \multicolumn{3}{|c|}{ Bengalee Children $^{1}$} & \multicolumn{3}{|c|}{ Indian Children ${ }^{2}$} & \multicolumn{3}{|c|}{ Malaysian Children ${ }^{3}$} & \multicolumn{3}{|c|}{ African Children ${ }^{4}$} \\
\hline & $\begin{array}{c}\text { Weight } \\
\text { (Kg.) }\end{array}$ & $\begin{array}{l}\text { Height } \\
\text { (cm) }\end{array}$ & $\begin{array}{c}\text { BMI } \\
\left(\mathrm{Kg} / \mathrm{mt}^{2}\right)\end{array}$ & $\begin{array}{c}\text { Weight } \\
\text { (Kg.) }\end{array}$ & $\begin{array}{c}\text { Height } \\
\text { (cm) }\end{array}$ & $\begin{array}{c}\text { BMI } \\
\left(\mathrm{Kg} / \mathrm{mt}^{2}\right)\end{array}$ & $\begin{array}{c}\text { Weight } \\
\text { (Kg.) }\end{array}$ & $\begin{array}{c}\text { Height } \\
\text { (cm) }\end{array}$ & $\underset{\left(\mathrm{Kg} / \mathrm{mt}^{2}\right)}{\mathrm{BMI}}$ & $\begin{array}{c}\text { Weight } \\
\text { (Kg.) }\end{array}$ & $\begin{array}{c}\text { Height } \\
\text { (cm) }\end{array}$ & $\begin{array}{c}\mathrm{BMI} \\
\left(\mathrm{Kg} / \mathrm{mt}^{2}\right)\end{array}$ \\
\hline 6 & 17.4 & 120.6 & 13.7 & 16.3 & 107.0 & 14.5 & 20.1 & 116.5 & 14.8 & 19.7 & 115.3 & 14.8 \\
\hline 7 & 18.1 & 123.2 & 14.2 & 18.2 & 113.4 & 14.7 & 21.8 & 119.9 & 15.2 & 22.0 & 121.4 & 15.0 \\
\hline 8 & 19.7 & 127.8 & 14.2 & 20.1 & 118.6 & 14.9 & 23.9 & 123.5 & 15.7 & 24.3 & 126.0 & 15.3 \\
\hline 9 & 22.6 & 130.5 & 14.9 & 22.2 & 123.8 & 15.5 & 25.7 & 126.6 & 16.0 & 26.2 & 130.3 & 15.4 \\
\hline
\end{tabular}

1. Data collected from different rural primary schools in West Bengal (present investigation).

2. $\quad$ Data for Indian Children belonging to all income groups [5].

3. Data for children belonging to low income groups from Kuala Lumpur, Malaysia [18].

4. Heights and Weights of Barbadian School Children [19].

Malaysian boys showed a range of $13.1 \%$ to $21.3 \%$ higher values of weight and BMI (6.8-9.5\%) but the height had range of lower values (2.9\%-3.4\%) than that of Bengalee children. When the African children were compared with the studied Bengalee primary school boys of 6-9 years, the result showed that the weight and BMI were $13.2 \%-23.4 \%$ and $3.4 \%-8.0 \%$ higher respectively than the Bengalee primary school children of same age groups.

On the basis of $15^{\text {th }}$ and $85^{\text {th }}$ percentile values of body mass index (BMI), primary school children were categorized into normal weight, overweight and underweight [20]. From the results (Table 10) it was observed that most of the boys (76.8\%) had normal body weight and only a little number of boys was overweight $(7.8 \%)$ or under nutrition $(10.7 \%)$. The standards of nutrition among school children in the present study were much higher than those found in Delhi Corporation School as well as that in urban school children in Tirupati $[21,22]$. They found that prevalence of malnutrition were $50 \%$ and $47 \%$ respectively. Another report focused that prevalence of malnutrition up to $34.20 \%$ in Kerala school children [23]. The other study also showed that $90 \%$ of the
Oraon children of 6-12 years were undernourished [24]. It was further observed that the highest percentages (about $20.19 \%$ ) of underweight boys were found in the age group of 8 years.

Tables 11 and 12 show the different skin folds thickness and body composition parameters by age groups of studied children. The percentage of body fat and total body fat were significantly $(p<0.01)$ different between all of the age groups. The lean body mass value was increased according to the increment of age and probably due to the enhancement of body muscle mass.

When the studied groups were compared (Table 11) it was noted that the age groups of 9 years had significantly higher percentage of body fat $(p<0.001)$ as well as total fat $(p<0.001)$ than that of the other age groups. This might be due to higher energy intake (Table 4). The relationships between BMI and percentage of body fat and BMI and lean body mass have been presented for the children of studied age groups in Figures $\mathbf{4}$ and $\mathbf{5}$ respectively. The results indicated that there was a positive significant correlation between BMI and percentage of body fat 
Table 10: Mean \pm SD, Percentile Values and Classification of B.M.I of Primary School Children

\begin{tabular}{|c|c|c|c|c|c|}
\hline \multirow{2}{*}{\multicolumn{2}{|c|}{ B.M.I. $\left(\mathrm{Kg} / \mathrm{mt}^{2}\right)$}} & $\begin{array}{l}6 \text { years } \\
(n=101)\end{array}$ & $\begin{array}{l}7 \text { years } \\
(n=102)\end{array}$ & $\begin{array}{l}8 \text { years } \\
(n=103)\end{array}$ & $\begin{array}{l}9 \text { years } \\
(n=104)\end{array}$ \\
\hline & & $\begin{array}{c}12.09 \pm 2.81 \\
(7.80-19.93)\end{array}$ & $\begin{array}{c}12.02 \pm 3.35 \\
(7.39-26.57)\end{array}$ & $\begin{array}{c}12.19 \pm 3.02 \\
(8.02-21.81)\end{array}$ & $\begin{array}{c}13.32 \pm 3.54 \\
(8.00-22.29)\end{array}$ \\
\hline \multicolumn{2}{|c|}{$5^{\text {th }}$ percentile value of B.M.I. } & 7.3692 & 6.402 & 7.1164 & 7.3728 \\
\hline \multicolumn{2}{|c|}{$85^{\text {th }}$ percentile value of B.M.I. } & 15.14 & 16.05 & 16.4 & 17.7 \\
\hline \multirow{2}{*}{$\begin{array}{c}\text { Over Weight } \\
\left(>85^{\text {th }} \text { to }<95^{\text {th }} \text { percentile }\right)\end{array}$} & Total & 9 & 8 & 4 & 11 \\
\hline & Percentage & $8.91 \%$ & $7.84 \%$ & $3.89 \%$ & $10.57 \%$ \\
\hline \multirow{2}{*}{$\begin{array}{c}\text { Normal Weight } \\
\left(5^{\text {th }}-85^{\text {th }} \text { percentile }\right)\end{array}$} & Total & 75 & 84 & 78 & 78 \\
\hline & Percentage & $74.26 \%$ & $82.35 \%$ & $75.73 \%$ & $75 \%$ \\
\hline
\end{tabular}

$\mathrm{n}$ indicates numbers of children were taken for the study.

Table 11: Different Skin Folds Thickness (Mean \pm SD) of Bengalee Primary School Chldren (all Measurements in $\mathrm{mm}$ )

\begin{tabular}{|c|c|c|c|c|}
\hline \multirow{2}{*}{ Skin fold } & \multicolumn{5}{|c|}{ Age Groups } \\
\cline { 2 - 5 } & $\mathbf{6}$ years $(\mathbf{n = 1 0 1})$ & $\mathbf{7}$ years $(\mathbf{n = 1 0 2})$ & $\mathbf{8}$ years $(\mathbf{n}=\mathbf{1 0 3})$ & $\mathbf{9}$ years $(\mathbf{n}=\mathbf{1 0 4})$ \\
\hline \hline Chest & $4.19 \pm 1.09$ & $3.51 \pm 0.67$ & $4.01 \pm 0.9$ & $3.81 \pm 0.63$ \\
\hline Abdomen & $3.93 \pm 0.9$ & $3.56 \pm 0.65$ & $4.16 \pm 0.71$ & $4.02 \pm 0.62$ \\
\hline Thigh & $5.02 \pm 0.99$ & $4.34 \pm 1.4$ & $4.59 \pm 1.41$ & $4.31 \pm 1.29$ \\
\hline
\end{tabular}

$\mathrm{n}$ indicates numbers of children were taken for the study.

Table 12: Different Body Composition Parameters of Primary School Children

\begin{tabular}{|c|c|c|c|c|}
\hline \multirow{2}{*}{ Age Groups } & Body Density (gms/cc.) & Percentage of body Fat (\%) & $\begin{array}{c}\text { Total Body Fat } \\
(\mathrm{Kg})\end{array}$ & Lean Body Mass (LBM) (kg) \\
\cline { 2 - 5 } & $1.104 \pm 0.001$ & $1.813 \pm 0.474$ & $0.302 \pm 0.116$ & $17.226 \pm 4.553$ \\
\hline \hline 6 yrs $(n=101)$ & $1.098 \pm 0.002$ & $0.714^{\star} \pm 0.494$ & $0.133^{\star} \pm 0.017$ & $18.122 \pm 4.387$ \\
\hline $7 y r s(n=102)$ & $1.097 \pm 0.001$ & $1.093^{*} \# \pm 0.579$ & $0.243^{\star} \# \pm 0.128$ & $19.622 \pm 4.494$ \\
\hline 8 yrs $(n=103)$ & $1.097 \pm 0.001$ & $1.115^{\star} \# \$ \pm 0.544$ & $0.249^{\star} \# \pm 0.140$ & $22.579^{\star *} \# \# \pm 5.878$ \\
\hline 9 yrs $(n=104)$ & 0.002 & $23.43(p<0.01)$ & $15.45(p<0.01)$ & 3.073 \\
\hline F Value & & & \\
\hline
\end{tabular}

wrt 6years age group, ${ }^{*} p<0.001 ; * * 0.01$.

wrt 7 years age group, $\# p<0.001 ; \# \# p<0.02$.

wrt 8 years age group, ${ }^{\wedge} \mathrm{p}<0.001 ; n$ indicates numbers of children were taken for the study.

$(r=0.02 ; p<0.001)$ as well as BMI and lean body mass $(r=0.55 ; p<0.001)$ in Bengalee Primary school children and there were also a linear relationship had been found in each group.

\section{DISCUSSION}

Cereals constitute the bulk of the daily diet for Bengali population. But cereals proteins are poor in nutritive quality, being deficient in the essential amino acids. However, if cereals are eaten with pulses, as is common in the traditional Indian diets, cereals and pulse proteins complement to each other and provide a more balanced diet. It was observed from the results that the amount of cereals, green leafy vegetables, other vegetables, taken by the boys of $6-9$ years $(5.3 \%$, $14.4 \%$, and $4.0 \%$ respectively) were close to the recommended values of NNMB but the values of pulses, milk and oil were remarkably lower (29.7\%, 


\section{Body Mass Index (BMI) vs. \% of Body Fat \\ (Casewise MD deletion) \\ $\%$ of Body Fat $=.88632+.00377 *$ BMl \\ Correlation: $r=.02087$}

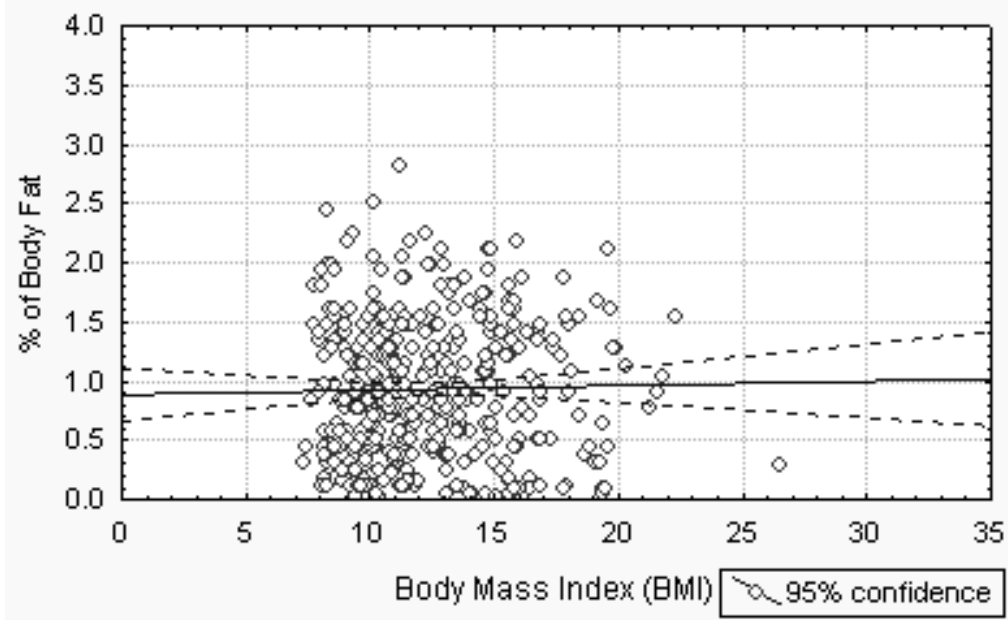

Figure 4: Relation between body mass index and Percentage of body fat and regression line for Bengalee primary school children.

Body Mass Index (BMI) vs. Lean Body Mass

(Casewise MD deletion)

Lean Body Mass $=8.7308+.86101{ }^{*}$ Body Mass Index (BMI)

Correlation: $r=.54613$

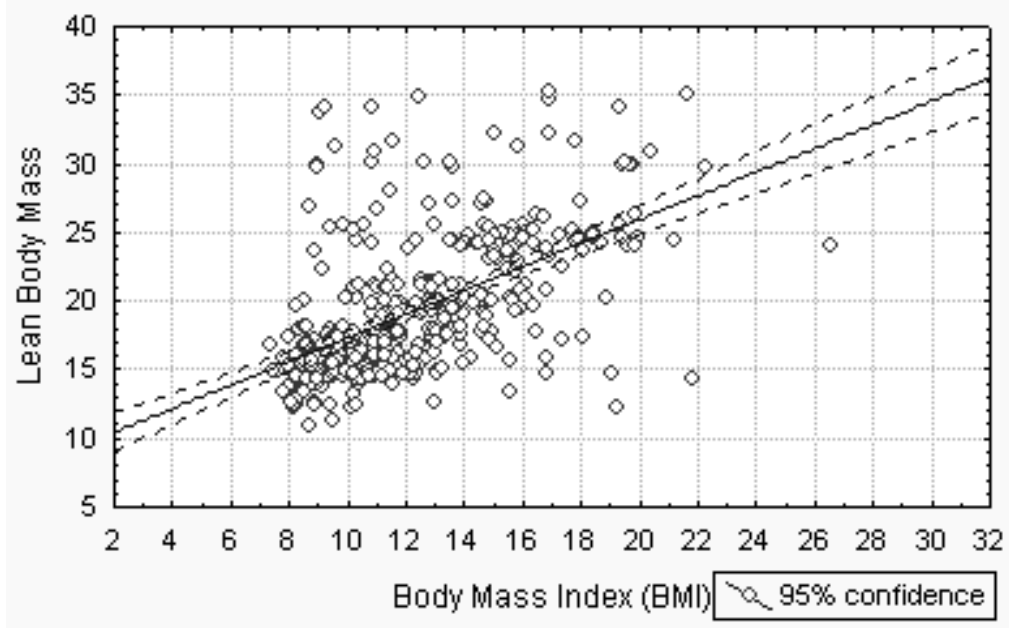

Figure 5: Relation between body mass index and lean body mass and regression line for Bengalee primary school children.

$66.9 \%, 54.8 \%)$ than that of the NNMB (2002) recommended values. For the age group of 8-9 years, It has been revealed that the amount of cereals, leafy and other vegetables, roots and tubers and sugar uptake were more $(10.1 \%, 17.2 \%, 13.6 \%, 83.5 \%$, $34.2 \%$ respectively) than that of the said NNMB recommendations but there was deficit in the uptake of milk and oil $(71.8 \%$ and $52 \%)$. As milk is a fine blend of all the nutrients necessary for growth and development of the young ones, possibly, the milk consumption is less probably due to lower economic status. The proportions of cereal to pulse were 10:1 and 8.6:1 respectively for both age groups as against 9:1 ratio suggested by Indian Council of Medical Research (1996).

From the above study, it was revealed that among the top 10 most frequently consumed foods of the respondents, as a mainly carbohydrate based diet was followed. Cereal is consumed mainly among the rural community of West Bengal, the variety within the cereal group is limited, as mainly rice, puffed rice and wheat 
are consumed. Although dairy products, food items from the protein-rich food group and fruit appeared largely in the list of rarely consumed items, these were consumed by only a small percentage of the respondents.

Although the protein intake was apparently adequate in children, the proteins were mainly of plant origin with low nutritional value. The low intake of animal protein $(21.5 \%)$ is typical for studied rural school children who obtain more $(78.5 \%)$ of their protein from plant sources. Although in theory, combinations of proteins from different plants in the right proportions can give amino acid profiles comparable to those of animal proteins [25]; this is not the case when a high proportion of the protein comes from cereal. The community should be encouraged to use the animal proteins, in order to improve the amino acid balance. In addition, increased consumption of milk should be promoted. In advising the community, it should be pointed out that the diet should be adequate in energy, since energy spares protein [26].

The ratio of protein energy to total energy (PE ratio) has been regarded as a convenient and useful descriptor of one aspect of dietary quality in human nutrition. For this purpose, the reference PE ratio was calculated as the simple ratio of protein requirements (expressed as equivalent energy) to energy requirements. Protein energy ratio (\%) less than $4 \%$ is recommended as poor nutritional intake status by ICMR. From the study, it was revealed that though very little numbers of the studied children $(7.1 \%)$ were unable to satisfy the required protein-energy ratio, it should not be ignored but given emphasis upon appropriate remedial measurements.

The peak velocities of Indian primary school boys, given by ICMR, are different from that of the present study. It may be noted that peak velocities of weight of the Bangalee boys are found at the age of 9 years where it was seen at both 8 and 9 years for Indian primary school boys recommended by ICMR (2010). According to the Tanner stage, the development stages were assessed which was a good indicator for actual growth rate of the children and also supports the degree of physical development.

From the result, it was also revealed that the maximum deviation of height, weight and BMI were found in the children of age group 8 years of Bengalee children when compared with the Indian, Malaysian and African children of same age. However, the
Bengalee boys are taller and heavier when they are compared to the Indian boys considering all income groups. BMI is based on the premise that body mass corrected for stature is correlated with adiposity [27]. $\mathrm{BMI}$ is moderately correlated with body fat; it also shows that BMI is correlated with fat-free mass. These findings support the observations of Garn et al., in that BMI may actually be a better indicator of lean tissue than of relative fatness [28].

\section{CONCLUSION}

With the enhancement of age the nutrient intake is increased which in turn related to the growth of the children. The consumption of protein and energy of the boys was lower than the recommended values of NNMB. However, there was a predominantly more calories deficiency in comparison to the protein deficiency. The protein energy ratio of the boys was lower than that of the ICMR recommended values. Most of the Bengalee boys had normal BMI values; only a little percentage of the subjects were over nourished or under nourished. The number of underweight boys (about 20\%) was the maximum in the age group of 9 years among all the age groups. In summary, the present study provides further evidence that the predictive accuracy of assessing socio economic status, nutritional intake, BMI, percentages of body fat, Tanners stages and other parameters varies considerably with children, and supports as the benchmark for determining nutritional status.

\section{ACKNOWLEDGEMENT}

The school authorities, all children and the parents who participated in the study are acknowledged for their cooperation and support.

\section{REFERENCES}

[1] Zanvar V, Devi R. Influence of educational and occupational status of parents on anthropometric measurements of selected adolescent girls. J Daiying Foods H.S 2007; 26(1): 23-32.

[2] Gopalan C, Rama Sastri BV, Balasubramanian SC. Nutritive value of Indian foods. National Institute of Nutrition, Indian Council of Medical Research. Hyderabad 2004.

[3] Swaminathan M. Essentials of Food and Nutrition. Vol. I and II. The Bangalore Printing and Publishing Co. Ltd. Bangalore 1999.

[4] I.C.M.R. Growth and Physical development of Indian infants and children. Technical report series no. 18, Indian Council of Medical Research, New Delhi 1989.

[5] NNMB. Diet and Nutritional Status Of Rural Population. Technical Report No.21, National Nutrition Monitoring Bureau, Hyderabad 2002. 
[6] Kumar N, Gupta N, Kishore J. Kuppuswamy's socioeconomic scale: Updating income ranges for the year2012. Indian $\mathrm{J}$ Pub Health 2012; 56(1): 103-104.

[7] McGraw-Hill. Food Composition Table, New York: McGrawHill Companies Inc. 2009.

[8] Ermacova SV, Podstavkina TP, Strokina AN. Anthropometric Atlas, Recommendation of methods. New Delhi: Amerind publishing Co.Pvt. Ltd 1985.

[9] Weiner JS, Lourie JA. Human Biology: A guide to field methods. IBP Hand Book No.9. Oxford: Blackwell Scientific Publications 1969.

[10] Johnson BL, Nelson JK. Practical measurement for evaluation in physical education. New York: Macmillion publishing Company 1986; pp. 174-20.

[11] Jackson AS, Pollock ML. Generalized Equations for predicting body density of men. Br J Nutr 1978; 40: 497-504. http://dx.doi.org/10.1079/BJN19860057

[12] Jackson AS, Pollock ML. Ward A. Generalized equations for predicting body density of women. Med Sci Sports Exer 1980; $12: 175-82$ http://dx.doi.org/10.1249/00005768-198023000-00009

[13] Siri WE. Gross composition of the body. In: Lawrence JH, Tobias CA, editors. Advances in Biological and Medical Physics. New York: Academic Press 1956.

[14] Hamilton J. The Boys' Growing Up in the Lord: Tanner Stage Calculator for Boys, version 2.3; c2011 (Last modified: August 26, 2012): Available from: http://growingupboys.info/ Calculators/TannerStage.htm.

[15] Gopalan C, Rama Sastri BV, Balasubramanian SC. Nutritive value of Indian foods. In: Nutrition Atlas of India. 2nd edition. National Institute of Nutrition, Hyderabad: Indian Council of Medical Research 1971; pp. 1-115.

[16] National Cancer Institute (Homepage on the Internet) DHQ website. Coding Manual for the $2010 \mathrm{NCl}$ Diet History Questionnaire II. Risk factor monitoring method. U.S National Institute of Health; 2010: Available from: http:// www.riskfactor.cancer.gov/dhq2.

[17] I.C.M.R. Nutrient Requirements and Recommended Dietary Allowances for Indians. A Report of the Expert Group of the Indian Council of Medical Research, New Delhi 2010.
[18] Shariff ZM, Bond JT, Johson NE. Data for children belonging to low income groups from Kuala Lumpur, Malaysia. Mal J Nutr 2000; 6: 17-32.

[19] Standard KL, Lovell HG, Harney L. Heights and Weights of Barbadian School Children. Br J Prev Soc Med 1966; 20(3): 135-40.

[20] Cole TJ, Bellizzi MC, Flegal KM, Dietz WH. Establishing a standard definition for child overweight and obesity worldwide: international survey. BMJ 2000; 320: 1240-3. http://dx.doi.org/10.1136/bmj.320.7244.1240

[21] Dhingra DC, Anand NK, Gupta S. Health status of school children of various socio-economic groups. Ind Pediatr 1977; 14: $243-46$.

[22] Indirabai K, Malika R. A comprehensive study of school children of Tirupati city, Andhra Pradesh. Ind Pediatr 1976; 13: $751-58$

[23] Gangadharan M. School health service programme in Kerala, a rural study. Ind Pediatr 1977; 14: 603-13.

[24] Mittal PC, Srivasatava S. Diet, nutritional status and food related traditions of Oraon tribes of New Mal (West Bengal), India. Rural Remote Health 2006; 6: 385.

[25] Muroki NM. Improvement of the nutritional value and organoleptic and keeping quality of unfermented and fermented rice "uji" (porridge) with haricot bean (Phaseolus vulgaris) tempe. Research Report. Bogor, Indonesia: Nutrition Research and Development Centre 1990

[26] Passmore R, Eastwood MA. Human nutrition and dietetics. Hong Kong: Longman Group 1986; pp. 279-91.

[27] Eston RG, Rowlands AV, Charlsworth S, Davis A, Hoppitt T. 'Prediction of DXADetermined Whole Body Fat From Skinfolds: Importance of Including Skinfolds from the Thigh and Calf in Young Healthy Men and Women'. Eur J Clin Nutr 2005; 59: 695-702

http://dx.doi.org/10.1038/sj.ejcn.1602131

[28] Garn S, Leonard W, Hawthorne V. 'Editorial: Three Limitations of the Body Mass Index'. Am J Clin Nutr 1986; 44: 996-7. 